\title{
Pharmacognosy Ethnopharmacology: a laboratory science?
}

\author{
Eliana Rodrigues ${ }^{1,4}$ \& Danilo Ribeiro de Oliveira ${ }^{2,3}$
}

\begin{abstract}
In 1962, Richard Evans Schultes defined ethnobotany as "the study of the relationships which exist between people of the primitive society and their plant environment". Ethnopharmacology, considered a sub-discipline of ethnobotany, has been conceptualized in different ways over time. Since the 80 's, implicit in these different concepts was the need for the validation of traditional/popular knowledge through pharmacological and phytochemical studies. According to these ideas, plants or animals identified during fieldwork should be investigated by these sciences in order to prove or disprove their "empirical" use, only resulting in an ethnopharmacological study if they passed through the methodologies of "academic laboratory science". The historical trajectory of these concepts leads us to think that ethnopharmacology is a science only if tested and proven, without considering or recognizing the knowledge of other cultures as a science in itself. We present here some examples from traditional medicine hoping to bring a conceptual, holistic, practical and ethical reflection on the theme.
\end{abstract}

Key words: ethnopharmacological study, fieldwork, laboratory science, laboratory study, scientific proof.

\section{Resumo}

Em 1962, Richard Evans Schultes define a Etnobotânica como “...o estudo das relações que existem entre povos de uma sociedade primitiva e seu ambiente vegetal”. A Etnofarmacologia, como uma subárea da Etnobotânica, vem recebendo diversos conceitos ao longo do tempo. A partir dos anos 80, começa a ficar implícito nestes conceitos a necessidade de validação dos conhecimentos tradicionais/populares pelos estudos farmacológicos e fitoquímicos. De acordo com essas ideias e conceitos, plantas ou animais identificados durante o trabalho de campo deveriam ser investigados por essas ciências para provar ou refutar seu uso "empírico", só resultando em um estudo etnofarmacológico se fossem submetidas às metodologias da "ciência acadêmica laboratorial”. A trajetória histórica desses conceitos nos faz pensar que a etnofarmacologia só é ciência se testada e comprovada, não enxergando ou reconhecendo o conhecimento das outras culturas, como uma ciência em si. Nesse contexto, apresentamos alguns exemplos práticos da medicina tradicional, com a esperança de trazer uma reflexão conceitual, holística, prática e ética sobre o tema.

Palavras-chave: estudo etnofarmacológico, estudo de campo, ciência laboratorial, estudo laboratorial, comprovação científica.

Ethnobotanical studies involving plant records, their uses and therapeutic forms (medicinal plants) by human groups have provided the basis for several basic and applied studies, especially in the field of phytochemistry and pharmacology, also being used as a tool for the discovery of new drugs. Within this context, ethnopharmacology has been viewed as a branch of Ethnobiology/ Ethnobotany that deals with medical practices, especially remedies used in traditional medical systems. But how is ethnopharmacology defined by academia?

\footnotetext{
${ }^{1}$ Universidade Federal de São Paulo, Center for Ethnobotanical and Ethnopharmacological Studies, R. Arthur Riedel 275, Diadema, SP, 09972-270, Brazil.

${ }^{2}$ Universidade Federal do Rio de Janeiro, Faculty of Pharmacy, Lab. Bioprospecting and Applied Ethnopharmacology, Av. Carlos Chagas Filho 373 , Rio de Janeiro, RJ, 21941-902, Brazil.

${ }^{3}$ ORCID: <https://orcid.org/0000-0001-5697-6510>

${ }^{4}$ Autor para correspondência:68.eliana@gmail.com
} 
In 1962, Richard Evans Schultes defined ethnobotany as "the study of the relationships which exist between people of the primitive society and their plant environment". Ethnopharmacology, considered a sub-discipline of ethnobotany, has been conceptualized in different ways over time. In 1988 the same author defined ethnopharmacology as: "It refers, of course, to the medical or pseudomedical use of plants and animals by pre-literate societies - but it is much more than that. It is a branch of the growing interdisciplinary field called ethnobotany - which has developed so rapidly in recent years that it now has subdivisions, such as ethnopharmacology, ethnomicology, ethnoecology, archaeobotany, etc ...".

Since the 80's, implicit in these different concepts was the need for the validation of traditional/popular knowledge by pharmacological and phytochemical studies:

Bruhn \& Holmstedt (1982) conceptualized ethnopharmacology as "the multidisciplinary scientific exploration of biologically active agents traditionally employed or observed by man". Holmstedt \& Bruhn (1983) understood that "Ethnopharmacology refers to the observation, identification, description and experimental investigation of the ingredients and the effects of indigenous drugs". Elizabetsky \& Coelho-deSouza (2004) states that "the ethnopharmacological approach consists of combining information acquired from local communities that make use of medicinal flora with chemical/pharmacological studies carried out in specialized laboratories. The ethnopharmacological method allows the formulation of hypotheses regarding the pharmacological activities and active compounds responsible for the therapeutic actions reported by the user populations".

Heinrich (2014) highlighted ethnopharmacology as "a scientific approach to the study of biological activities of any preparation used by humans, which have, in a very broad sense, either beneficial or toxic or other direct pharmacological effects". On this basis, the author claimed that ethnopharmacology does not attempt to describe the uses of plants (usually local or traditional), but involves a broad study of these preparations according to the associated anthropologicalpharmacological-toxicological areas.

However, these latter definitions somehow establish a link between 'traditional', 'popular' and 'academic' knowledge, so that data from field surveys must be tested and proven (validated) by academic science. According to these ideas and concepts, plants, fungi or animals identified during fieldwork should be investigated by academic science in order to prove or disprove their "empirical" use, only resulting in an ethnopharmacological study if they pass through the methodologies of academic laboratory science. Nevertheless, this was not the original idea of this discipline which was intended to observe and describe the medicine of other cultures (Schultes 1962).

These definitions lead us to think: Is it always possible for academic science to validate traditional knowledge?

In this context, Heinrich et al. (2009) stated that "It is also important to recognize that the logic of non-western cultures is often more expansive than is our more science-driven system of thought. Thus, in many traditional societies, there are at least as many plants used "magically" - to protect infants from witches or evil spirits, to enhance an athlete's performance or to help one run faster, to find animals more effectively, or to make one's arrow fly straighter - as there are for the mundane concerns of treating diarrhoea or sore eyes. Frequently, the same plant has both types of uses; often one cannot understand the logic of the use of a plant in the second category without understanding it in the first".

Thus, for example, can the effectiveness of the use of two plants employed by Krahô Indians which are tied to women's bellies days before and during sex and which are considered to determine the child's sex, be proven by the methods of preclinical pharmacology? (Fig. 1). Another example is the cigarette called "removing the devil", containing nine strongly aromatic plants and used by quilombolas living in Mato Grosso State, Brazil, in order to fortify the brain (Rodrigues et al. 2008). It is recommended for persons suffering from nervous breakdown due to overwork, being also used by teenagers and children to improve their performance in learning skills. How to conduct preclinical pharmacology studies with a cigarette consisting of nine plants, considering all possible combinations between plants until finding the best combination aiming at the desired effect, although the medium $^{1}$ has explained that three of the nine plants are those of superior importance for the final effect of the cigarette? Also, in this case, the quantity and proportion of each ingredient need to

\footnotetext{
Status that the Afro-Brazilian religions attribute to someone who has accumulated extensive experience in healing activities with the help of the spirits.
} 


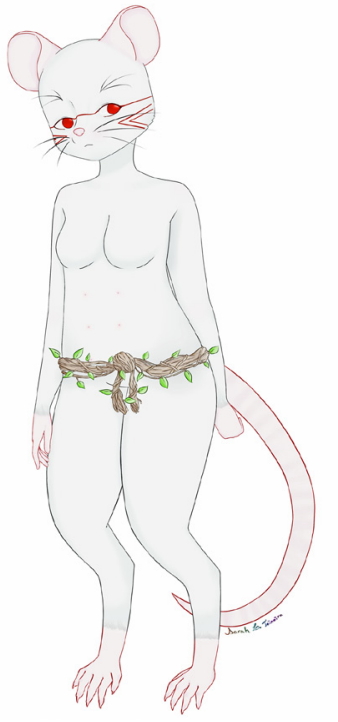

Figure 1 - A rat with a knot in its belly with the objective of validating the traditional knowledge of the Krahô Indians by academic science.

be determined considering the fieldwork data. It is not an easy task! Finally, what may the expected biological effect be in laboratory tests? Nootropic? Antipsychotic? Soothing? Stimulant?

Oliveira \& Leitão (2016) describe the difficulty in extrapolating possible indications of traditional use to laboratory tests in order to perform bioprospecting studies based on the associated traditional knowledge. When studying quilombola communities in Oriximiná-PA, the authors searched for plants indicated for: 1treatment of tuberculosis, pneumonia, cough, and chest diseases, with possible antimycobacterial activity; 2- treatment of malaria, high fever, liver diseases, with possible antiplasmodic activity; 3- memory loss, Alzheimer's disease etc., with possible acetylcholinesterase inhibitory activity. However, the results confirmed the fact that local communities practice a peculiar form of diagnosis and treatment focusing on the individual according to their holistic perception, rather than considering him a therapeutic target or considering the disease alone. Thus, an individual may be in an imbalanced condition which, if not corrected, cannot be cured, whether it involves tuberculosis, poor memory or malaria, often requiring the use of tonic, fortifying, invigorating, and purifying plants, among others. Many of these plants have adaptogenic, antioxidant, anti-inflammatory, immunostimulating and immunomodulatory properties, among others, being responsible for strengthening the body and restoring health, even indirectly healing or improving the quality of life of the individual.

During fieldwork it is observed that some ethnopharmacological data are difficult or even not possible to test in laboratory, since biomedicine does not provide preclinical trials for them. One of these examples is some of the native plants of the Brazilian Cerrado employed in the medicine of the Krahô Indians (Rodrigues \& Carlini 2005). Thus, how to "measure" in the laboratory: 1) the 13 plants indicated by them for social relations (to prevent matrimonial separation, to attract someone, to steal a man from his wife, to marry, to divorce, to fall in love)?; 2) the 8 plants considered to be thought modifiers (that help thinking, that rest the head, that cause a person to have an open mind, that help clear one's thoughts)?; or 3) the 5 plants used as strengtheners for babies' legs, in a process involving scarification of the legs of babies at about 6 months of age so that they will start walking earlier?

Similarly, it is difficult to test in laboratory animals the plants that are used in shamanic contexts, aimed at contact with the supernatural, and which generally alter perception, often called hallucinogens. The Amazonian Indians of Brazil use the resins of several Virola species belonging to the Myristicaceae family, such as: V. calophylla (Spruce) Warb., V. calophylloidea Markgr., V. elongata Benth. Warb. and $V$. theiodora (Spruce ex Benth.) Warb. for making a snuff known as ebena, nakwana, ukuna, yato, paricá, epená, and yakee (Schultes 1979). Also resins of species of the genus Anadenanthera, such as A. peregrina (L.) Speg. (Leguminosae) are used in the same way by Brazilian Indians (Farnsworth 1968). These are just two examples of substances used during shamanism among so many other recordings made by ethnobotanists and ethnopharmacologists from around the world among the 26 Brazilian indigenous ethnic groups (Yazbek et al. 2018).

If not ethnopharmacology, what other academic discipline would record in depth the knowledge that involves plants, animals, fungi and minerals in a cultural context? Academic science may try to prove these uses of traditional medicine, but this does not exclude the fact that these reports alone, if well detailed, are within the ambit of the Ethnopharmacology discipline!

And even if traditional knowledge is proven or not by academic methods, should this knowledge be disqualified? Returning to the definition of 
ethnobotany proposed by Schultes in 1962, and assuming that the two disciplines have similar etymology, would not ethnopharmacology be the study of the relationship between populations and the substances that interact in living organisms? The historical trajectory of these concepts leads us to think that ethnopharmacology is only a science if tested and proven by «academic laboratory science» without considering or recognizing the knowledge of other cultures as a science in itself. But, is the validation of traditional medicine by academic science the most intelligent way to analyze traditional medicine?

Although Etkin (2001) provided an utilitarian view of ethnopharmacology, she made an important reflection on the risks of scientific bias in this approach by exemplifying pharmacological studies directed at angiotensin-converting enzyme (hypotensive) or antiplasmodic activity, considering that: 1- in both cases, the applications tested are only remotely related to those for which indigenous populations use the plants; 2- there is insufficient ethnographic content to ensure that the dilution and extraction mode in which the plants are laboratorytested corresponds to how indigenous healers prepare and administer those plants in preventive and therapeutic medicine. To conclude, the author points out that "In these cases, readers cannot judge whether traditional therapeutic objectives overlap biomedical ones - for example, these plants may not be intended to reduce blood pressure and parasite load, but instead to cause sweating to chase the disease agents from the body.".

Different methods are used by the "science" of the cultures that develop these types of medicine (Strauss 1989); among them, following "sensorial clues" allied to the Doctrine of Signatures ${ }^{2}$ recommended by Paracelsus (1493-1541), observing the behaviour of some animals in the consumption of plants, and using intuition, among others (Bennett 2007; Rodrigues 2007; Leonti 2011). Moreover, such knowledge is not static but is tested and improved every day, just as academic science, although using different methods (Strauss 1989). Thus, it may not be appropriate to superimpose the methods of academic science on these methods during the analysis of this knowledge.

As an example, we may consider a cigarette used by the Krahô Indians called caprankohirehô, the literal translation of this vernacular term being leaf of 'turtle spine', which refers to its

\footnotetext{
${ }^{2}$ According to this Doctrine it is possible to recognize the peculiarities and virtues of each herb by its "signature" (shape, form, color).
}

pharmacological effect of inducing 'slowness'. The Krahô Indians discovered a use for these plants after observing that deer that consumed them were easier to hunt since they moved more slowly.

Another example that elicits curiosity and respect for traditional knowledge comes from Africa (Davis 1988). The beverage prepared from the plant Calabar bean or Ese're nut (Physostigma venenosum Balf.) is used during community trials in order to determine the culpability of a suspected murderer. The suspect(s) must drink the beverage during an event that counts on the presence of the community. The suspect who dies after drinking it is considered guilty. The explanation is physiological and psychological. People in the community know that the culprits die during this ceremony and therefore the culprit will hesitate to drink the beverage, that is, he will drink it slowly, while innocent persons drink it all at once. Because it is a poisonous drink, as the scientific name of the plant itself reveals, the person who drinks it all at once will vomit immediately and the substance will not act on his organism. Thus, he will not die and will be considered "innocent". On the other hand, the "culprit", being scared, will drink it slowly, so that the poisonous substance will be quickly absorbed by his organism, with a consequent heart attack followed by death. The question that concerns us is: how did these people achieve this knowledge and follow this practice?

Another example observed in Brazil, as intriguing as those cited above, is the Ayahuasca drink, whose elaboration involves the use of several species of the genus Banisteriopsis (family Malpighiaceae), mainly Banisteriopsis caapi (Spruce ex Griseb.) Morton and Psychotria viridis R. et P. Dimethyltryptamine, present in the latter species, alters perception if inhaled, but its activity is neutralized by the enzyme monoamine oxidase (MAO) when the potion is ingested orally. In this respect, a drink prepared only with this plant would have no activity. However, B. caapi contains $\beta$-carboline alkaloids such as harmine, harmaline and tetrahydroharmalin. These active principles inhibit MAO, and for this reason the final effect of the beverage is the action of dimethyltryptamine, since in pharmacology the inhibition of an inhibition results in an action. Academic science knows that harmine and its derivatives, present in these species of Banisteriopsis, have this function in order to potentiate the action of dimethyltryptamine in the beverage (Schultes \& Hofmann 1993). But the question is: how did the indigenous peoples of the 
Amazon discover that the combination of these two species could lead to the final entheogenic effect, i.e., a change of perception that causes the person to "contact his inner God"?

Petiveria alliacea L. (Phytolaccaceae), is a native Brazilian plant involved in another curious example. It is popularly known as amansa-senhor ('sir taming'), making a link with slave use in Brazil, where it was a weapon against their masters. Thus, women slaves who suffered sexual abuses from their masters, and who were also their cooks prepared 'magic drinks' and administered them to their masters in small doses in their foods over a long period of time to inhibit their libido and also 'to weaken their brain', so that they would enter a state of starvation and die slowly (Camargo 2007). Another example involving the eighteenth-century slavery period in Haiti is the illustrious voodoo priest known as François Mackandal. After six years of voodoo plant poisoning, causing the death of 6,000 Frenchmen (settlers of Haiti), he was betrayed by one of his "friends," captured and burned in a public square (Mocombe 2010). The knowledge and use of plants as chemical weapons by enslaved Africans in various countries is an example of how these peoples had to learn about the uses of plant resources available in the new environments to which they were subjected.

The zombification process, still occurring today in Haiti and the Dominican Republic and detailed by Davis (1988) is no less interesting. Some sorcerers use two types of poison to "kill" a chosen person, i.e., frog skin - a depressor of smooth muscle that causes hypothermia and a fall in metabolism and plants of the genus Datura containing anticholinergic agents such as atropine and scopolamine. After receiving these two substances the person is apparently dead and then buried. After a while the person returns, appearing to bealive and then serving as a slave having lost his free will and opinion. The sorcerer, on the night of the funeral, goes to the grave and removes from the coffin the person (now a zombie), who then wakes up from the actions caused by the drug received, showing delirium, loss of consciousness, transient anterograde amnesia, submissive behavior and apathetic behavior.

According to these and many other examples, it is evident that there are methods for acquiring knowledge that are not based only on chance or simply on trial and error, as commonly and simplistically alleged. But ethnopharmacology has been long characterized by autilitarian approach, depending on the experimentation and biological validation of the therapeutically employed natural agents. For example, Gottlieb \& Borin (2004) defended chemosystematics as the most promising and advanced scientific strategy to be used to research natural products, showing a contempt for ethnopharmacology and fieldwork, stressing that "most existing customs have been investigated and the acculturation of primitive people is very fast at present". So they proposed "to replace tribal empiricism by modern science". The authors still relate ethnopharmacology to laboratory research by saying that "the natural distribution of plant products, endowed with the desired properties, could be investigated quickly, free from the tedious effort required to demystify popular beliefs", although they themselves questioned the possibility of rationalizing indigenous practices by scientific arguments.

The ethnopharmacology conceptual discussion, though somewhat forgotten, has definitely made progress. Leonti (2011) highlights the relevance of the philosophical approach in ethnopharmacological research, re-reading the predictions made by Robbins et al. (apud Leonti 2011) a century ago about ethnobotany, mentioning the need to "strike deeper into the thoughts and life of the people studied", and that its studies should progress to a point where results can be studied comparatively, arguing that "both utilitarian and philosophical approaches should contain a research question, i.e. a reasonable hypothesis that can be proven right or wrong with the application of a sound method".

An important contribution in this regard is the discussion among ethnopharmacologists about minimum ethical and methodological aspects in field research, valuing scientific rigor in order to obtain reliable and relevant results for society, starting from the elaboration of clear field research questions, hypotheses and objectives (Heinrich et al. 2009; Leonti 2011; Weckerle et al. 2018). The "Rules of 5" established by the Journal of Ethnopharmacology (JEP) in 2006 provided specific rules for "Immediate rejection criteria" for manuscripts, including a specific rule regarding field ethnopharmacological data. Later, Heinrich et al. (2018) presented for the first time in the field of ethnopharmacology a community-wide document that defines guidelines for best practice on how to develop, conduct, and record field work, including studies using historical approaches, named as Consensus Statement on Ethnopharmacological 
Field Studies (ConSEFS). Therefore, there is no doubt that in the last 2 decades there has been an advance in the standards of excellence of ethnopharmacological field studies, which, when well conducted, have been scientifically legitimized, regardless of whether or not they include complementary laboratory data.

In the past (2005), the International Society of Ethnopharmacology described this discipline as an: "Interdisciplinary study of the physiological actions of plant, animal and other substances used in indigenous medicines of past and present cultures". Today, this society has a broader approach, "We are a small, collaborative, interdisciplinary group of scientists -anthropologists, pharmacists, pharmacologists, ethnobotanists, phytochemists, and others - all fascinated by the study of the global use of medicines. We are particularly concerned about understanding the medicinal uses of plants in traditional societies. We seek to understand the cultural and the pharmacological dimensions of human medicinal plant use everywhere" (ISE 2019). Other authors have also considered a broader and less exclusive and utilitarian approach to the definition of this discipline. For example, Dos Santos \& Fleurentin (1990) conceptualize Ethnopharmacology as: "an interdisciplinary scientific study of materials of animal, plant or mineral origin and related knowledge and practices that different cultures use to modify the state of a living organism through therapeutic (curative/prophylactic) or diagnostic purposes". These last definitions, like that of Schultes (1988), consider "the medical practices of these different medicinal substances".

Nevertheless, most of the scientific journals that deal with the ethnopharmacology topic publish articles focused on a logic approach, i.e., biomedicine validating traditional medicine. There must be recognition that there are different ways of doing science using different methods, and that if biomedicine cannot "measure" and has no methods for the observation of a traditional use, this does not mean that it has no value, but rather that it has a real or symbolic value for the society that uses it.

\section{Acknowledgements}

We thank all the interviewees who participated in the Ethnobotanical/Ethnopharmacological studies described in this paper. We also thank two anonymous referees for their helpful suggestions in improving this paper. The authors also thanks FAPESP - Fundação de Amparo à Pesquisa do Estado de São Paulo and CAPES - Coordenação de Aperfeiçoamento de Pessoal de Nível Superior, for financial support.

\section{References}

Bennett BC (2007) Doctrine of Signatures: An explanation of medicinal plant discovery or Dissemination of knowledge? Economic Botany 61: 246-255

Bruhn JG \& Holmstedt B (1982) Ethnopharmacology: objectives, principles, and perspectives. In: Reinhard E \& Beal JL (eds.) Natural products as medicinal agents., Hippokrates, Stuttgart. Pp. 405-430.

Camargo MTLA (2007) Contribuição etnofarmacobotânica ao estudo de Petiveria alliacea L. -Phytolacaceae-(“amansa-senhor") e a atividade hipoglicemiante relacionada a transtornos mentais. Dominguezia 23: 21-28.

Davis W (1988) Passage of darkness: the ethnobiology of the Haitian zombie. University of North Carolina Press, Carolina. 365p.

Dos Santos JR \& Fleurentin J (1990) L'ethnopharmacologie, une approche pluridisciplinaire in Ethnopharmacologie: sources, méthodes, objectifs. Actes Du 1er Colloque Européen d'Ethnoparcologie, ORSTOM, Metz. Pp. 26-39.

Elizabetzky E \& Coelho-de-Souza G (2004) "Etnofarmacologia como ferramenta na busca de substâncias ativas" In: Simões CMO, Schenckel EP, Gosmann G, Mello JCP, Mentz LA \& Petrovick PR (eds.) Farmacognosia: da planta ao medicamento". $5^{\text {a }}$ ed. Ed. UFRSG, Ed. UFSC, Porto Alegre, Florianópolis. Pp. 107-122.

Farnsworth NR (1968) Hallucinogenic plants. Science 162: 1086-1092.

Gottlieb OR \& Borin MRMB (2004) “Quimiossistemática como ferramenta na busca de substâncias ativas" In: Simões CMO, Schenckel EP, Gosmann G, Mello JCP, Mentz LA \& Petrovick PR (eds.) Farmacognosia: da planta ao medicamento". $5^{\text {a }}$ ed. Ed. UFRSG, Ed. UFSC, Porto Alegre, Florianópolis. Pp. 107-122.

Heinrich M, Edwards S, Moerman DE, Leonti M (2009) Ethnopharmacological field studies: a critical assessment of their conceptual basis and methods. Journal of Ethnopharmacology 124: 1-17.

Heinrich M (2014) Ethnopharmacology: quo vadis? Challenges for the future. Brazilian Journal of Pharmacognosy 24: 99-102.

Heinrich M, Lardos A, Leonti M, Weckerle C, Willcox M, Applequist W, Ladio A, Long CL, Mukherjee P \& Stafford G (2018) Best practice in research: Consensus Statement on Ethnopharmacological Field Studies - ConSEFS. Journal of Ethnopharmacology 211. 
Holmstedt BO \& Bruhn JG (1983) Ethnopharmacology - a challenge. Journal of Ethnopharmacology 8: 251-256.

ISE - International Society of Ethnopharmacology (2019) Website Introduction of the International Society for Ethnopharmacology. Available at $<\mathrm{https}$ ://www. ethnopharmacology.org/> . Access on 24 June 2019.

Leonti M (2011) The future is written: impact of scripts on the cognition, selection, knowledge and transmission of medicinal plant use and its implications for ethnobotany and ethnopharmacology. Journal of Ethnopharmacology 134: 542-555.

Mocombe PC (2010) Why Haiti is maligned in the Western world. The contemporary significance of Bois Caiman and the Haitian Revolution. Encuentros 16: 31-43.

Oliveira DR \& Leitão SG (2016) Fortifier, tonic, and rejuvenating plants and the adaptogen concept. In: Albuquerque UP (org.) Introduction to ethnobiology. Springer. Pp. 151-162.

Rodrigues E \& Carlini EA (2005) Ritual use of plants with possible action on the central nervous system by the Krahô Indians, Brazil. Phytotherapy Research 19: 129-135.

Rodrigues E (2007) Plants of restricted use indicated by three cultures in Brazil (caboclo-river dweller, Indian and Quilombola). Journal of Ethnopharmacology 111: 295-302.
Rodrigues E, Gianfratti B, Tabach R, Negri G \& Mendes FR (2008) Preliminar investigation of the effects on the central nervous system of tira-capeta (removing-thedevil), a cigarette utilized by some Quilombolas living in Brazil. Phytotherapy Research 22: 1248-1255.

Schultes RE (1962) The role of the Ethnobotanist in search for new medicinal plants. Lloydia 25: 257- 366.

Schultes RE (1979) Indícios da riqueza etnofarmacológica do noroeste da Amazônia. Acta Amazonica 9: 209-15.

Schultes RE (1988) Ethnopharmacological Conservation: A key to progress in medicine. Acta Amazonica 18: 393-406.

Schultes RE \& Hofmann A (1993) Plantas de los dioses: origenes del uso de los alucinógenos. Fondo de Cultura Económica, Ciudad del México. 192p.

Strauss CL (1989) O pensamento selvagem. Cia. das Letras, São Paulo. 324p.

Yazbek P, Sauini T, Machado FCS, Negri G \& Rodrigues E (2018) Plants used for Central Nervous System Disorders by Brazilian Indians. In: Martinez JL, Muñoz-Acevedo A \& Rai M (orgs.) Ethnobotany: application of medicinal plants. CRC Press, Taylor \& Francis Group. Pp. 56-68.

Weckerle CS, de Boer HJ, Puri RK, van Andel T, Bussmann RW \& Leonti M (2018) Recommended standards for conducting and reporting ethnopharmacological field studies. Journal of Ethnopharmacology 210: 125-132. 